VOCES DEL COMITÉ EDITORIAL

Rev Chil Salud Pública 2014; Vol 18 (2): 203-205

\section{ACHIEVING UNIVERSAL HEALTH COVERAGE: THE GLOBAL HEALTH POLITICAL QUEST}

Iniciamos esta sección a partir de este número, con el propósito de invitar a miembros de nuestro equipo editorial a expresar su voz, no sólo en materias de salud pública, sino también inquietudes y sugerencias editoriales.

Universal Health Coverage (UHC) has been posed as the corner stone for global health debate. The 2010 World Health Report depicted UHC as a strategy throughout its member States advocate to design, or even to reform, their health financing systems so all people could have access to health services without suffering financial hardship. ${ }^{1}$ Nevertheless, it seems that meanings, pathways, and scope of UHC are still lacking a shared vision for global health policy advocates.

Although the United Nation Post-2015 Development Agenda compels countries worldwide to focus their efforts on effective governance of systems for social development, ensuring affordable universal coverage and quality service delivery for the most deprived groups of population, ${ }^{2}$ the politics of global health have been underestimated at the level of UHC policy diffusion. Moreover, assuming UHC as primarily an economic quest instead of a political one has moved the global community toward a misguided debate.

A broader set of theoretical frameworks with policy recommendations on how to design and implement UHC in different health systems settings have been addressed. ${ }^{3-6}$ Nonetheless, it is the UHC financial core, which is not only supported by an important group of global health advocates, but is also refuted by those who see UHC as a broader political and development challenge world wide. ${ }^{7-10}$ In fact, the UHC financial core causes a political debate worldwide since it implies an ideological dilemma on countries' political economy.

Hidden behind a technical financial debate, the politics of UHC have not surpassed the fact that, first of all, domestic politics are beyond global politics. Whereas for developed countries economic crisis makes cutting social welfare budgets the main policy option for macroeconomic instability, political struggles for running current UHC schemes become a domestic political issue. The global landscape for UHC, as a global health imperative, has shown how the role of States and ideologies on public health matters in designing and implementing UHC.

Can this global landscape for UHC be overcome? While global health is seen as a philanthropic pursuit rather than the responsibility of States, 
boundaries on what should be done by States on global health will continue to drive the debate. Overmatching it would imply examining what kind of globalization we are considering and whether or not it will be worthwhile. Furthermore, it would imply seeking a debate free of mislead rhetoric concerning financial-based UHC and the role of politics in its implementation.

As an example, in low-and middle- income countries, global health means more than financial aid but also social and political development. Fragile State and social clashes drive UHC to a political quest instead a financial one. At some point of the debate, it seems that global health stakeholders and advocates are quite confident that policy diffusion would be enough to persuade governments to move toward UHC. From a global perspective, disowning the impact of UHC over domestic health and social welfare leads us to grasp global health not only as a threat in the poorest, but also in the richest countries.

Although the current global health efforts are committed to a better life and dignity for all human beings, there is not a shared vision on why countries should embrace UHC as a path for social development. For some developed countries, moving forward into better health and social welfare schemes could still be seen as an economic and political threat; they will continue attracting people from poorest countries who are seeking a better quality of life. Developed countries with strong migration policy could take advantage of new social and cultural backgrounds, which could move ideological boundaries regarding UHC. Undoubtedly, the second scenario would be the best for global health efforts.

During recent decades, some Latin American countries have strived to gather political will as a key driver for moving toward UHC. Moreover, some are actually trying to overcome path dependency by designing new financial and governance arrangements, allowing them to move away from an individualistic conception of social welfare schemes to a social one. Consequently, they have been able to advance in discussion con- cerning the politics and policies of health systems. Chile was mentioned in the $\mathbf{2 0 1 0}$ World Health Report as one of the countries moving toward UHC, but their political institutions are far from being aligned with changes that UHC demands for better social welfare and population health levels. There is also a governance barrier within the Chilean health system, which does not allow it to conceive UHC beyond a strategy for health care financing.

What can be done about it? The most important premise: Reaching UHC as a global health goal demands countries to examine the global economic model. Although this premise could be considered naive, it is central for changing health from a for-profit good to a social right. Thus, discussion is not only about health financing systems and payment methods, but also about the meaning of health under global economic policies.

While democracy is seen as a path to protect the economic model benefiting global elites but not the pathway to distribute power among societies, UHC seems neither achievable nor comprehensive for the most vulnerable societies. Therefore, harnessing global economic development as a bargaining threat for moving toward UHC should not be used at seeking and attaining a global consensus. On the contrary, achieving UHC as a global health tenet will require strong cultural and social background support from all countries. Strengthening democracy as a fair political system can allow distribution of power among -and within-societies, instead of being a protection system for an economic model. Thus, when referring to UHC we will be debating not only on how to redistribute power among -and within- societies as the path to reduce global health shortfalls, but also global social and human rights.

\section{REFERENCES}

1. World Health Organization. The World Health Report 2010. Health systems financing: the path to universal health coverage. Geneva: WHO; 2010. 
2. United Nations. Realizing the future we want for all. Report to the Secretary-General. New York: UN; 2012.

3. Koon AD, Mayhew SH. Strengthening the health workforce and rolling out universal health coverage: the need for policy analysis. Glob Health Action. 2013; 4: 10.3402/gha. v6i0.21852. Published online 2013 July 24. DOI: 10.3402/gha.v6i0.21852.

4. Kutzin J. Health financing for universal health coverage and health system performance: concepts and implications for policy. Bull World Health Organ. 2013; 91: 602611.

5. Fattore G, Tediosi F. The importance of values in shaping how health systems governance and management can support universal health coverage. Value Health. 2013; 16: S19-S23.
6. Borgonovi E, Compagni A. Sustaining universal health coverage: the interaction of social, political, and economical sustainability. Value Health 2013; 16: S34-S38.

7. O'Connell T, Rasanathan K, Chopra M. What does universal health coverage means? Lancet 2014; 383: 277-79.

8. Garret L, Mushtaque A, Chowdhury R, Pablos-Méndez A. All for universal health coverage. Lancet. 2009; 374: 1294-99.

9. Carrin G, Mathauer I, Xu K, Evans DB. Universal coverage of health services: tailoring its implementation. Bull World Health Organ. 2008; 86: 857-863.

10. Bennett S, Ozawa S, Rao KD. Which path to universal health coverage? Perspectives on the World Health Report 2010. PLoS Med. 2010; 7(11): e1001001. DOI: 10.1371/ journal.pmed.1001001. 